\title{
Further Notes on the Young Gobiidæ from the Neighbourhood of Plymouth.
}

\author{
By \\ Marie V. Lebour, D.Sc. \\ Naturalist at the Plymouth Laboratory.
}

THE above paper on the Plymouth gobies (p. 48) was finished and in print before the new work of C. G. J. Petersen ("Beretning til Landbrugsministeriet fra den danske biologiske Station," XXVI, 1919) came to hand. Although a second description and differentiation of the common forms is now unnecessary after his accurate and detailed account of them, yet as a corroboration of his identifications and as a record of the occurrence and distribution of the young gobies to be found at Plymouth (three of which are not described by Petersen), it seems advisable to keep the whole of my work intact, although in some measure it contains a repetition of the conclusions arrived at by him. I have therefore altered nothing, except adding the words "up to $14 \mathrm{~mm}$." with regard to Gobius pictus in the table, p. 79, and merely confine myself to a few notes in this appendix with regard to any slight differences between his specimens and those from Plymouth. The three species not described by Petersen, namely Gobius elongatus, Gobius Jeffreysii and Gobius paganellus are apparently, with the exception of Gobius Jeffreysii, not present at all in the Danish waters. On reading his conclusions as to the specific value of the number of vertebræ and fin rays I feel still more strongly that the form hitherto known as the deep water form of Gobius minutus, and which I have here distinguished as Gobius elongatus, is a true species, although closely related to Gobius minutus.

Petersen shows, and my notes agree with him, that Gobius minutus, microps and pictus are distinct species, separable by the number of vertebræ and fin rays and also to a certain extent by their pigmentation. Since the above paper was written I have hatched the young of all three species (isolating the members of each species and obtaining the eggs from properly identified specimens), which agree well with Petersen's figures with the exception of some of the small spots on the head and the dorsal tail spots which differ slightly from the Danish specimens. In the Plymouth Gobius microps just hatched, there are two chromato- 
phores on the dorsal margin, one just above the anus, the other in the usual position opposite the large ventral ramifying chromatophore, the front one usually smaller, but both may be ramified. There is also a dorsal spot above the median head chromatophore (the median head chromatophore of Petersen is described by me as the large chromatophore beneath the auditory capsule, as it is median, Petersen's is the better term) similar to that in Gobius pictus, a spot behind the eye and one on the snout. The lower jaw spot and tongue spot are usually absent in the newly hatched Plymouth specimens.

The median head chromatophore is present in all three specimens when newly hatched. In Gobius minutus there is usually a small spot above it and again the lower jaw spot is usually absent, and on the dorsal margin there is often present a chromatophore opposite to the anus, as in Gobius microps, and there may also be a spot behind the eye which is also present in Gobius pictus. In Gobius Ruthensparri the dorsal spot above the median chromatophore is also present. It is thus evident that small variations are common in the pigmentation of the newly hatched young.

The pigmentation of all three, Gobius minutus, microps and pictus, beyond about $12 \mathrm{~mm}$. seems to be developed rather earlier in the Danish specimens, especially the dorsal pigment. Further investigation has shown me that specimens of young Gobius minutus which have come up the estuaries may be much more pigmented than those from nearer the open sea, and that whilst the latter stay in the condition shown in Plate I, Fig. 1 of my paper on p. 56, and Petersen's Plate I, Fig. 7, up to $15 \mathrm{~mm}$. or more, those from up the river are much more like the Danish figure from 12 to $16 \mathrm{~mm}$. (Plate I, Fig. 8). A black chromatophore may be present dorsally at $12 \mathrm{~mm}$. in the position of the yellow chromatophore, described by Petersen.

Gobius pictus agrees well with Petersen's figure of 1919 up to $15 \mathrm{~mm}$., but his Figure 10, Plate I of 1917 of Gobius minutus-microps, which he now attributes to pictus, of $14.3 \mathrm{~mm}$., and which I regarded as microps is much more pigmented than the Plymouth specimens of $14 \mathrm{~mm}$. As the Danish specimens show dorsal pigment at the base of the first dorsal fin after $14 \mathrm{~mm}$., my table on page 79 should read, after IV A $b$ : No spot at the base of the last ray of 1st dorsal fin (up to $14 \mathrm{~mm}$.), the words in brackets being added. The sensory papillæ on the back of the pectoral fin of the adult male mentioned by Petersen are present in the Plymouth specimens. The appearance and disappearance of Gobius pictus in Danish waters is interesting; the adults are very common on sandy bottoms in the shallow waters of Plymouth Sound, half-grown specimens occurring sometimes, as recorded above, in the deeper waters.

Gobius Ruthensparri has, in all specimens counted from Plymouth, 
11 fin-rays in its second dorsal and anal fin; whereas this is rare in the Danish specimens, which usually have 10. Holt's Irish specimens also, with very few exceptions, have 11. Petersen records a few specimens having 31 vertebræ. With regard to his remark as to the last ray of the anal fin in gobies being double, it has here also always been counted as one.

In Aphya the Plymouth young so far examined have no pigment spot on the lower jaw which is usually present in the Danish specimens, and the Danish Crystallogobius young at $11 \mathrm{~mm}$. have ventral pigment along the tail, and at $9 \mathrm{~mm}$. a few spots ventrally and one dorsally ; my single specimen of $9 \mathrm{~mm}$., with no sail pigment, is therefore probably not typical. 